\title{
The application of an agro-hydrological model for a data limited closure study of a bauxite mine in Australia
}

\author{
HH Bulcock Klohn Crippen Berger, Australia \\ J Heaslop Klohn Crippen Berger, Australia
}

\begin{abstract}
Closure is a critical phase of a mining operation since this is when the environmental effects of mining and rehabilitation work, both biological and physical, are most stringently judged (Spain et al. 2015). This study considered the hydrological impacts of the final rehabilitated landform after closure relative to the pre-mine site. The bauxite mine is in Australia and hydrological data is limited. In order to compare the pre-mine condition to the final closure landform the Agricultural Catchments Research Unit (ACRU) agro-hydrological model was used as it can account for the changes in surface topography, soil profile and vegetation associated with mining. The assessment of the hydrological impacts included streamflow, baseflow, transpiration and peak discharge. Streamflow presents an integrated descriptor of the impact of the mining due to the removal of the bauxite layer from the soil profile and is affected by the quick flow and baseflow responses. Transpiration is an indicator of the vegetation water demands and provides insight into the species that should be used for rehabilitation. The peak discharge shows how the changes in the topography and land use will impact the functioning of the waterways post-closure. The aim of the final landform is to maintain the functioning of the waterways to as-close to the pre-mine conditions as possible. From the peak discharge output from the agro-hydrological model, the data was input into HEC-RAS 2D model to estimate the changes in flow velocity, shear stress, stream power and water surface elevation. The results from the study suggest that there is not a large change in flow volumes on an annual basis, but the peak discharge is reduced by up to $78 \%$ in some cases. The associated reduction in velocity, water surface elevation, shear stress and stream power are approximately $40 \%, 400 \mathrm{~mm}, 51 \%$ and $68 \%$ respectively. The findings from this study will provide context for potential remedial measure.
\end{abstract}

Keywords: agro-hydrological model, bauxite mine, closure, Australia

\section{Introduction}

Closure is a critical phase of a mining operation since this is when the environmental effects of mining and rehabilitation work, both biological and physical, are most stringently judged (Spain et al. 2015). This order of magnitude (OoM) study aimed to understand the hydrological impacts for closure design that could arise from the final landform and, to develop a closure work program for hydrological design works that will be required beyond the current standard rehabilitation practices. The rehabilitation of the mine takes place continuously and by the time the mining operations cease, most of the area will have been rehabilitated and present an almost complete final landform.

The site had no hydrological data in the form of streamflow monitoring for any period pre-mining or operational periods to calibrate or compare the model results. As such, a physically based hydrological model was required that was able to estimate the relative hydrological response to the changes to the landscape, primarily driven by changes to the soil profile as a result of the removal of the bauxite layer, as well as the change in vegetation and topography of the catchments. The Agricultural Catchments Research Unit (ACRU) agro-hydrological model was chosen as it has multi-soil layers which can be parameterised to account for the changes in soil thickness and texture. In addition, the model has a comprehensive land use, soil and vegetation parameter library that can be used in the absence of field data as was the case in this study. 


\section{$2 \quad$ Methodology and data}

\subsection{Site characteristics}

The key hydrological and hydraulic parameters required for the modelling are summarised in Table 1 . For this study, there are eight catchments, but catchments one to four will form the primary focus for the sake of brevity, but other catchments are discussed where deemed necessary.

Table $1 \quad$ Site characteristics

\begin{tabular}{lccccc}
\hline $\begin{array}{l}\text { Catchment } \\
\text { name }\end{array}$ & Area $\left(\mathbf{k m}^{\mathbf{2}}\right)$ & $\begin{array}{c}\text { Hydraulic } \\
\text { length }(\mathbf{m})\end{array}$ & Slope (\%) & $\begin{array}{c}\text { Area disturbed } \\
\left(\mathbf{k m}^{\mathbf{2}}\right)\end{array}$ & \% Disturbed \\
\hline Catchment 1 & 19.0 & 4,800 & 0.80 & 10.8 & 56.8 \\
Catchment 2 & 151.0 & 16,950 & 0.35 & 39.0 & 25.8 \\
Catchment 3 & 31.5 & 9,100 & 0.42 & 3.6 & 11.4 \\
Catchment 4 & 23.2 & 5,500 & 0.78 & 8.1 & 34.9 \\
Catchment 5 & 34.9 & 4,990 & 1.20 & 5.4 & 15.4 \\
Catchment 6 & 9.6 & 3,500 & 1.90 & 0.3 & 3.1 \\
Catchment 7 & 37.3 & 10,500 & 0.44 & 0.2 & 0.5 \\
Catchment 8 & 6.5 & 2,800 & 1.6 & 0 & 0 \\
Total & 313 & - & - & 67.7 & 21.6 \\
\hline
\end{tabular}

\subsubsection{Climate data}

The long-term daily climate data (i.e. rainfall and evaporation) for the site as used in the ACRU model was sourced from the Data Drill service for the period 1 January 1889 to 31 October 2018. The monthly rainfall and A-pan evaporation data is summarised in Tables 2 and 3 respectively.

Table 2 Summary of monthly rainfall data $(\mathrm{mm})$

\begin{tabular}{lrrrrrrrrrrrrr}
\hline Item & Jan & Feb & Mar & Apr & May & Jun & Jul & Aug & Sep & Oct & Nov & Dec & Annual \\
\hline Max & 730 & 635 & 951 & 996 & 424 & 112 & 95 & 23 & 75 & 188 & 288 & 747 & 2,491 \\
$90^{\text {th }} \%$ & 420 & 474 & 496 & 473 & 174 & 48 & 27 & 6 & 6 & 25 & 123 & 354 & 1,788 \\
Mean & 282 & 291 & 294 & 198 & 59 & 18 & 9 & 2 & 3 & 9 & 45 & 178 & 1,388 \\
Median & 275 & 266 & 279 & 131 & 23 & 9 & 3 & 1 & 0 & 2 & 25 & 151 & 1,356 \\
$10^{\text {th } \%}$ & 127 & 136 & 103 & 34 & 3 & 0 & 0 & 0 & 0 & 0 & 0 & 36 & 1,019 \\
Min & 30 & 71 & 31 & 9 & 0 & 0 & 0 & 0 & 0 & 0 & 0 & 0 & 592 \\
Std dev & 125 & 133 & 159 & 180 & 81 & 24 & 15 & 4 & 10 & 21 & 57 & 136 & 325 \\
\hline
\end{tabular}


Table 3 Summary of month A-pan evaporation data $(\mathrm{mm})$

\begin{tabular}{lrrrrrrrrrrrrr}
\hline Item & Jan & Feb & Mar & Apr & May & Jun & Jul & Aug & Sep & Oct & Nov & Dec & Annual \\
\hline Max & 239 & 186 & 193 & 210 & 208 & 197 & 218 & 238 & 240 & 250 & 235 & 243 & 2,435 \\
$90^{\text {th }} \%$ & 180 & 154 & 169 & 177 & 182 & 168 & 184 & 200 & 211 & 230 & 222 & 214 & 2,235 \\
Mean & 176 & 142 & 158 & 161 & 164 & 154 & 164 & 186 & 203 & 221 & 216 & 205 & 2,147 \\
Median & 180 & 141 & 159 & 160 & 161 & 150 & 161 & 182 & 202 & 220 & 219 & 210 & 2,146 \\
$10^{\text {th }} \%$ & 155 & 130 & 141 & 147 & 159 & 150 & 157 & 179 & 195 & 214 & 202 & 180 & 2,064 \\
Min & 123 & 113 & 125 & 109 & 133 & 125 & 132 & 158 & 174 & 184 & 174 & 141 & 1,871 \\
Std dev & 15 & 11 & 11 & 14 & 12 & 10 & 13 & 12 & 9 & 9 & 11 & 17 & 84 \\
\hline
\end{tabular}

\subsubsection{Vegetation and rehabilitation}

The native vegetation at the site is open forest or savanna dominated by Eucalyptus tetrodonta and Eucalyptus miniata (Fox et al. 2001). E. tetrodonta is a widespread species occurring in the tropical part of Australia. The rehabilitation has been taking place progressively since the inception of the mine and there are well established rehabilitated areas to compare the vegetation cover to unmined areas. The rehabilitated areas that are approximately 15 years or older resemble the unmined areas to a high degree. Based on these observations, the existing vegetation parameters used in the model were applied for the final rehabilitated landform for the OoM (high-level) hydrological modelling.

\subsubsection{Unmined soil}

Under the Australian soil classification (Isbell 2002), the dominant soils of the area are classified as bauxitic, dystrophic red kandosols. These soils were formerly known as bauxitic red earths (Stace et al. 1968) but would be classified as orthoplinthic ferralsols (McKenzie et al. 2004) under the World Reference Base (The International Union of Soil Sciences (IUSS) Working Group World Reference Base (WRB) 2007) and as oxisols under Soil Taxonomy (Soil Survey Staff 1999). The profile comprises a variably developed A horizon overlying a B horizon which increases in clay content with depth; this, in turn, overlies the indurated bauxitic layer. The term 'kandosol' implies soils that lack strong texture contrast, have only weakly structured B horizons and are not calcareous (Isbell 2002). Red kandosols are typically well drained, permeable soils with a clay mineralogy dominated by kaolinite and with small amounts of iron oxides. The term dystrophic refers to soils with a base status of less than $5 \mathrm{cmol} . \mathrm{kg}^{-1}$ of clay and a bauxitic horizon is one that has more than a visually estimated $20 \%$ of bauxitic nodules or concretions (Isbell 2002).

\subsubsection{Mined and post-mined soil}

No mining takes place within a $25 \mathrm{~m}$ buffer around the waterways. As a result, there is a raised area around the waterways as the areas outside of this buffer are lowered by the removal of the bauxite layer. The effect of this buffer around the waterways was considered in the hydrological and hydraulic modelling.

At the commencement of mining, $0.6 \mathrm{~m}$ of soil (where available) is removed and classified as topsoil regardless of the blend between A and B horizon materials. Material greater than $0.6 \mathrm{~m}$ is treated as subsoil and depending on quality, it is either stockpiled for future use or backfilled into laterite pits. 
The topsoil is of importance in that it provides suitable chemical and physical conditions for plant growth and comprises a valuable source of nutrients and native plant seed, notably of the understorey species. Stockpiling topsoil for extended periods is known to reduce seed viability and to diminish soil physical, chemical and biological fertility (Schäffer et al. 2007); top-soil is therefore moved directly to a new site that has previously been mined and the subsoil replaced (Banning et al. 2011) (Figure 1).

This process has become known as 'direct-return' soil handling and aims to maximise ecological benefit in terms of retaining fertility and life in the soil. Subsequent to soil replacement on the lowered post-mining landscape (Figure 1), the restored soil profile is deeply ripped ('sub-soiled') at a lateral interval of approximately $1.7 \mathrm{~m}$ (O'Keefe 1992) in order to de-compact soil materials compacted by heavy machinery traffic and to breakup the upper part of the mine floor (Croton \& Ainsworth 2007).

In this process, a straight tine is dragged through the reconstructed soil profile (both top and sub-soil) and to a depth into the upper part of the mine floor that depends on its degree of induration, typically 0.2 to $0.3 \mathrm{~m}$. Passage of this tine through the soil thereby creates physical conditions more amenable to root penetration and growth and to free drainage (Banning et al. 2011; Schäffer et al. 2007). The post-mined soils are highly permeable.

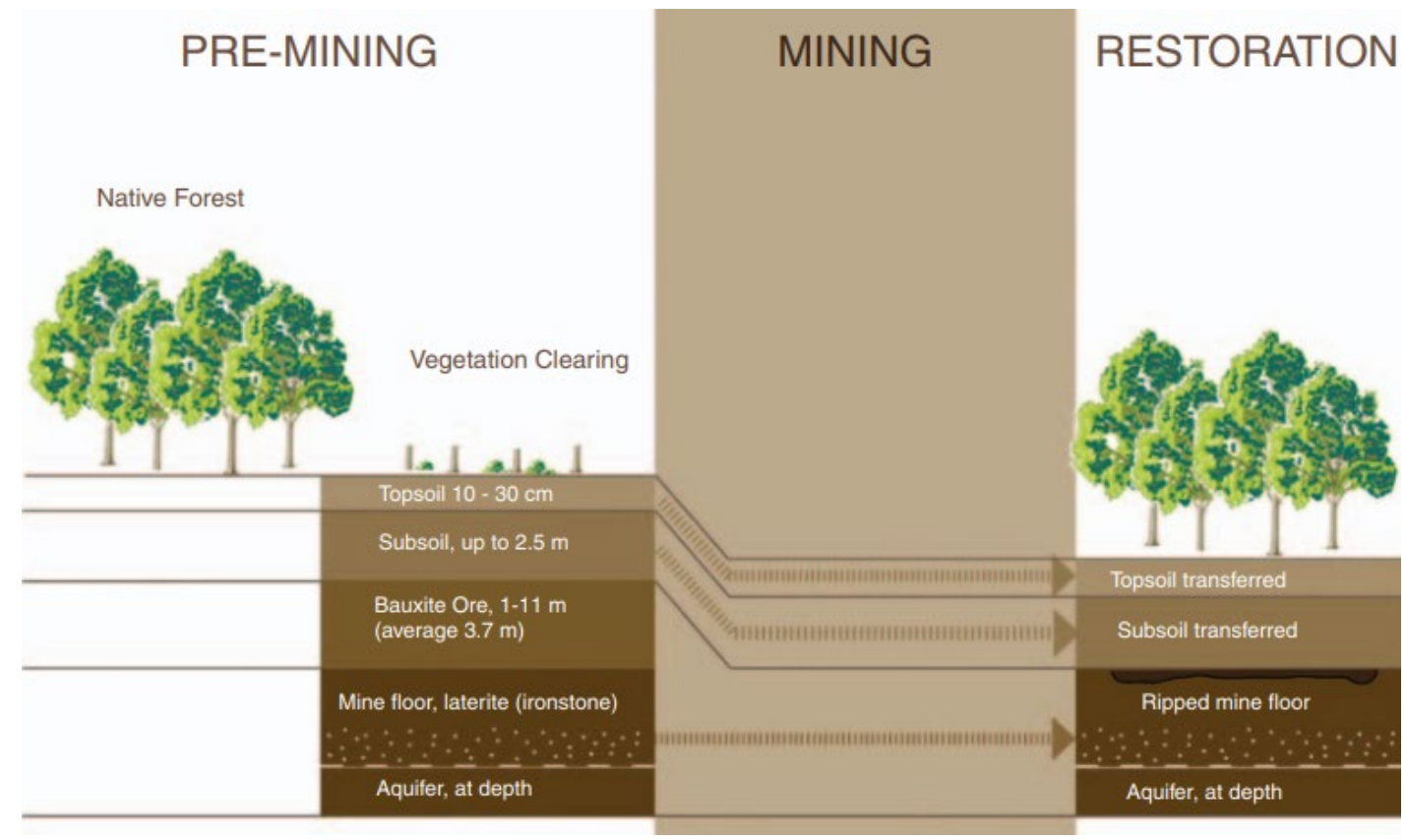

Figure 1 Schematic of the process of vegetation clearing, mining, soil replacement, profile ripping and restoration (after Spain et al. 2015)

\subsubsection{Soil data}

Particle size distribution (PSD) data was obtained for the red soils (oxisols) and the bauxite layer (Figure 2) from which the hydraulic properties could be estimated from the ACRU model soil parameter library (Table 4). From the PSD, the red soils were classified as 'sandy loam' and the bauxite layer as 'loamy sand'. 
PARTICLE SIZE DISTRIBUTION

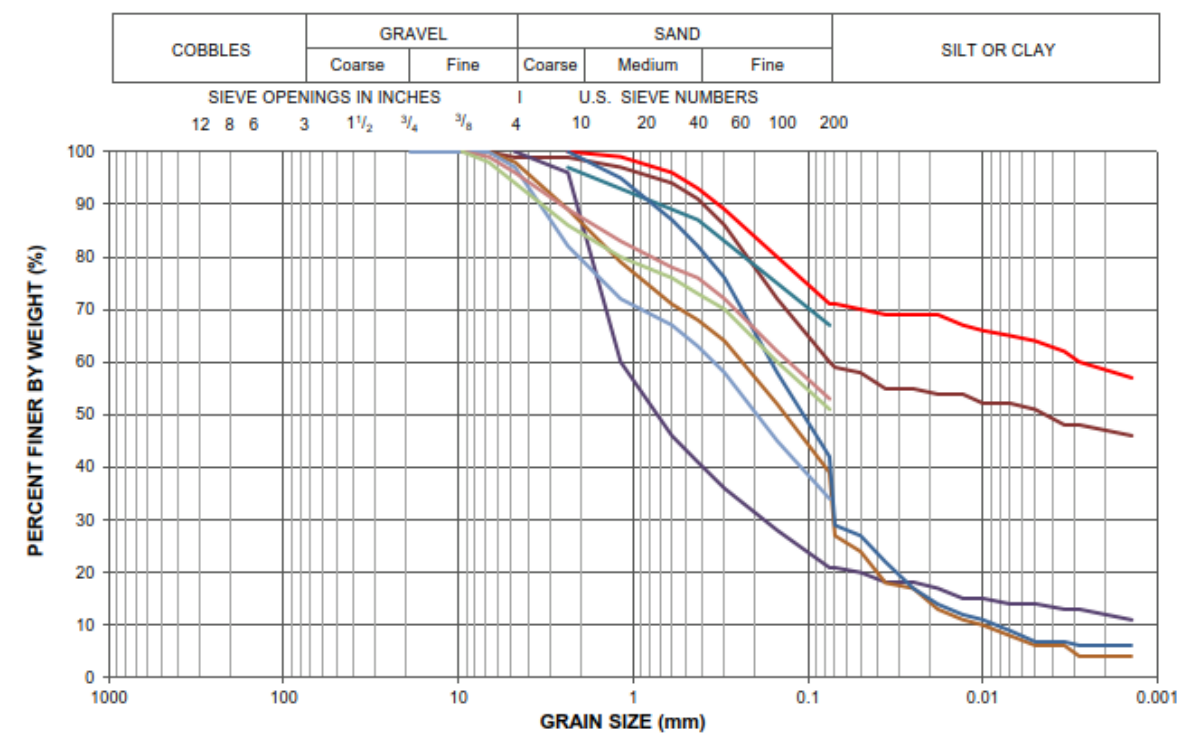

(a)

PARTICLE SIZE DISTRIBUTION

\begin{tabular}{|c|c|c|c|c|c|c|}
\hline \multirow{2}{*}{ COBbLES } & \multicolumn{2}{|c|}{ GRAVEL } & \multicolumn{3}{c|}{ SAND } & \multirow{2}{*}{ SILT OR CLAY } \\
\cline { 2 - 4 } & Coarse & Fine & Coarse & Medium & Fine & \multirow{2}{*}{} \\
\hline
\end{tabular}

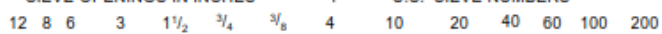

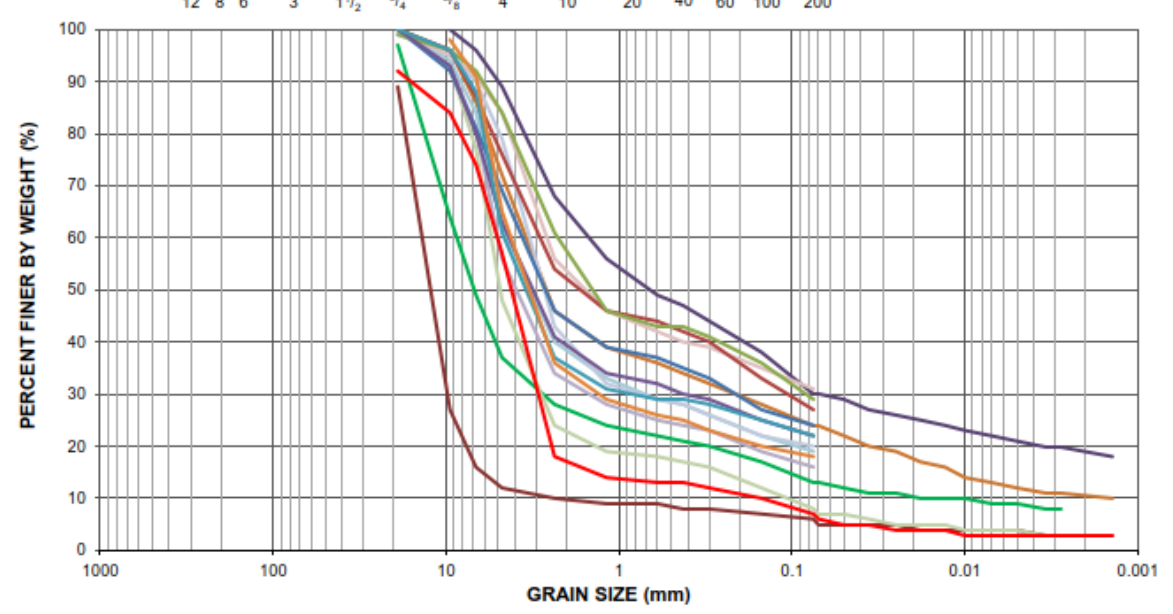

(b)

Figure 2 Particle size distribution data for (a) the red soils; and (b) the bauxite layer

Table 4 Soil water retention properties used in the ACRU model

\begin{tabular}{lccc}
\hline Texture class & $\begin{array}{c}\text { Permanent wilting } \\
\text { point }(\mathrm{m} / \mathrm{m})\end{array}$ & $\begin{array}{c}\text { Drained upper limit } \\
(\mathrm{m} / \mathrm{m})\end{array}$ & $\begin{array}{c}\text { Porosity } \\
(\mathrm{m} / \mathrm{m})\end{array}$ \\
\hline Loamy sand (bauxite) & 0.068 & 0.143 & 0.432 \\
Sandy loam (oxisol) & 0.093 & 0.189 & 0.448 \\
\hline
\end{tabular}

\subsection{Hydrological modelling}

The hydrological model aims to determine the pre- and post-mine hydrological conditions, which are changed due to the removal of the bauxite layer from the soil profile. The continuous simulation was run for 129 years and estimated the relative surface runoff, baseflow and transpiration. 
The ACRU agro-hydrological modelling system was developed at the School of Bioresources Engineering and Environmental Hydrology (formerly Department of Agricultural Engineering) at the University of KwaZuluNatal, Pietermaritzburg, South Africa. The model development started in the late 1970s (Schulze 1995) and has continued to present. ACRU is a multi-purpose, multi-level, integrated physical-conceptual model that is designed to simulate total evaporation, soil water and reservoir storages, land cover and abstraction impacts and runoff at a daily time step as illustrated in Figure 3. The ACRU model revolves around a multi-layer soil water budgeting with specific variables governing the atmosphere-plant-soil water interfaces. Surface runoff and infiltration are simulated using a modified Soil Conservation Services (SCS) equation (Schmidt \& Schulze 1987), where the daily runoff depth is proportional to the antecedent soil moisture content. As is the case with every integrated/multipurpose hydrological modelling system applied to simulate hydrological responses in large and heterogeneous watersheds, ACRU requires considerable spatial information, inter alia, topography, a wide range of climatic parameters, soils, land cover, reservoirs, and streams. The model has a comprehensive parameter library that can be used in the absence of field data for use in comparative studies.

\section{ACRU - Agrohydrological Model}

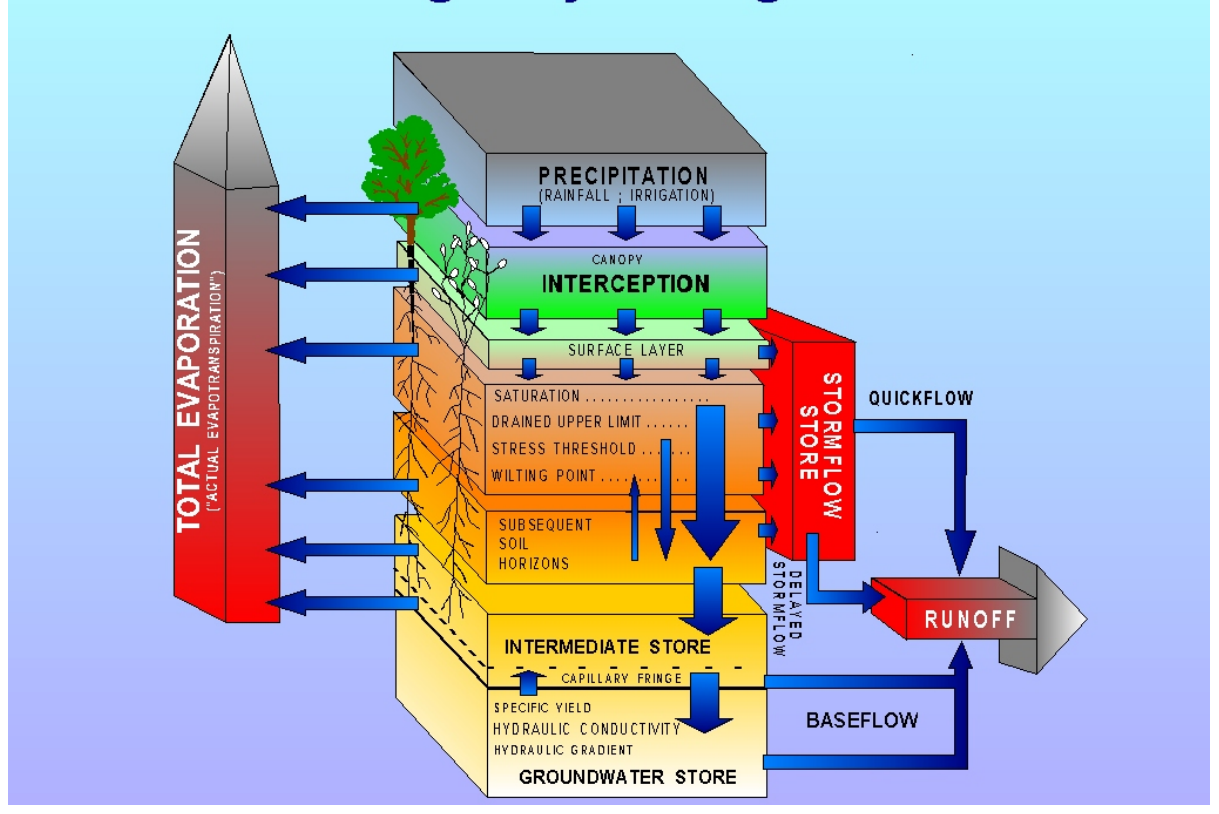

Figure 3 Conceptual schematic of the ACRU model structure

\subsection{Hydraulic modelling}

The hydraulic modelling was undertaken using the HEC-RAS Version 5.0.6 (US Army Corps of Engineers (USACE), June 2018) software package. HEC-RAS is a two-dimensional, multiple domain hydraulic model able to estimate the peak discharge, velocity and water surface elevation for the pre- and post-mine scenarios considered. It's noted that while no pre-mine topographic data was available, the hydraulic modelling assumed that the current geometry of the waterways remains reflective of the pre-mining conditions, with changes in catchment hydrology being the driver to establish relative changes between pre-and post-mining conditions. The peak discharge hydrographs generated from the ACRU hydrological model was used as the input into the hydraulic model. From the hydraulic model, the velocity, surface water elevation, shear stress and stream power were simulated to estimate the changes in flow characteristics of the waterways.

\section{Results and discussion}

The hydrological modelling results include runoff, peak discharge, baseflow and transpiration as they encompass responses to changes in topography, soil characteristics and vegetation. When modelling runoff, it is assumed that the whole catchment reports to the waterway and is not limited by the buffer or potentially 
increased evaporation of ponded water as there is no evidence to suggest that water ponds behind the buffers for long periods of time. The reason for including the runoff from the whole catchment is because it is not time-dependant (in the short-term) as is the case with peak discharge and that the water will eventually report to the waterways via baseflow. Peak discharge is however time-dependant and is a rapid response to a rainfall event and is dependent on the catchment characteristics such as time of concentration, catchment slope, runoff curve numbers and topography. Therefore, the peak discharge response is affected by the presence of the buffer areas around the waterways as the delayed response time will decrease the peak discharge. These assumptions should be considered as an area for potential refinement in future studies but would require additional data such as infiltration rates to gain an understanding of the time it takes for ponded water to infiltrate.

\subsection{Runoff}

Hydrological modelling results show that for all catchments there will be an increase in the runoff which is made up of both quick flow and baseflow. This is because of the bauxite layer being removed and therefore there is less soil to 'store' water before being released back to the receiving stream. The monthly comparison of runoff between pre- and post-mine conditions is shown in Figure 4. Catchment 1 is the most altered catchment and results in an annual increase in runoff of approximately $13.5 \%$ when compared to the premine (base) model predictions. Catchments 2, Catchment 3, Catchment 4 and Catchment 5 had an increase in runoff of $4.7 \%, 3.5 \%, 6.4 \%$, and $4.4 \%$ respectively. Seasonally, the runoff is higher in summer and lower in winter when compared to the pre-mine conditions. This is because the soil moisture store is depleted faster during the winter months when there is little or no rainfall. Conversely, during the high rainfall summer months, the soil recharges faster than the pre-mine conditions.

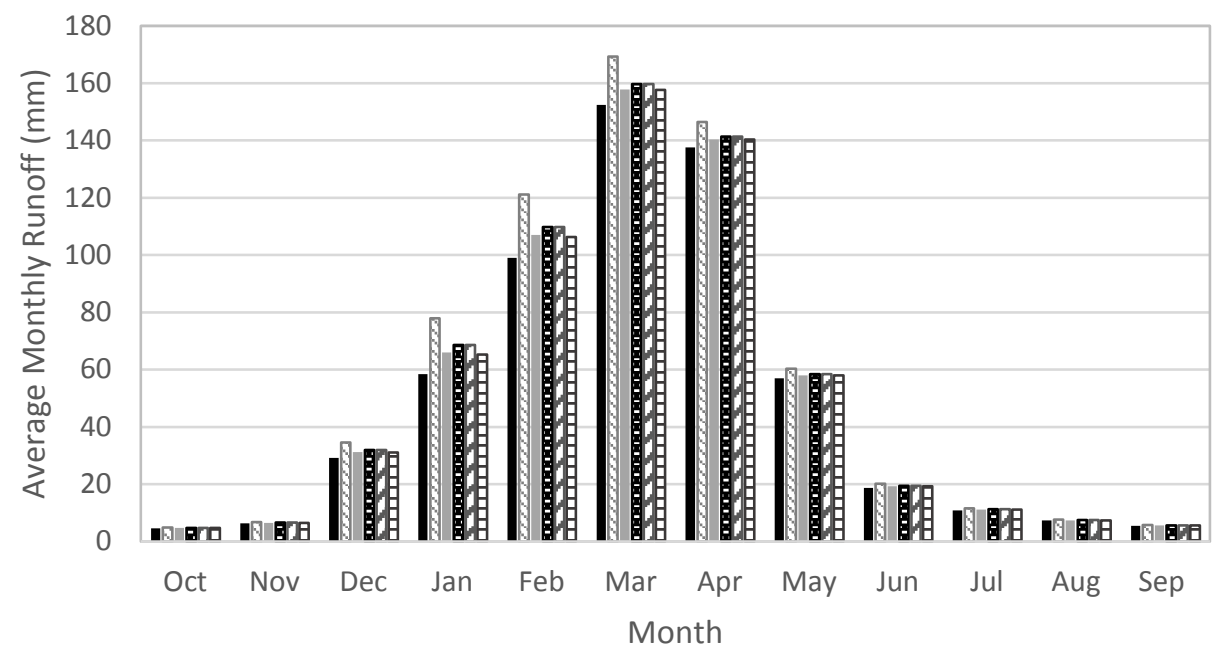

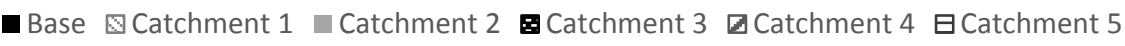

Figure 4 Comparison of changes in runoff depth relative to a pre-mine scenario

\subsection{Baseflow}

Due to the removal of the bauxite soil layer, the storage capacity of the soil profile is reduced. Because of the smaller storage capacity, the soil profile fills up faster and releases the water to groundwater or runoff. The most highly impacted catchment is Catchment 1 which has an increase in annual baseflow of approximately 18.6\%. Catchment 2, Catchment 3, Catchment 4, and Catchment 5 have annual increases of 7.6\%, 4.7\%, $10.2 \%$ and $6.8 \%$, respectively relative to the pre-mine (base) model predictions. However, when looking at the data at a monthly scale, the baseflow is lower during the winter months when compared to the pre-mine conditions. This is due to the soil moisture being depleted quicker by the vegetation for transpiration. The average monthly baseflow comparison is shown in Figure 5. 


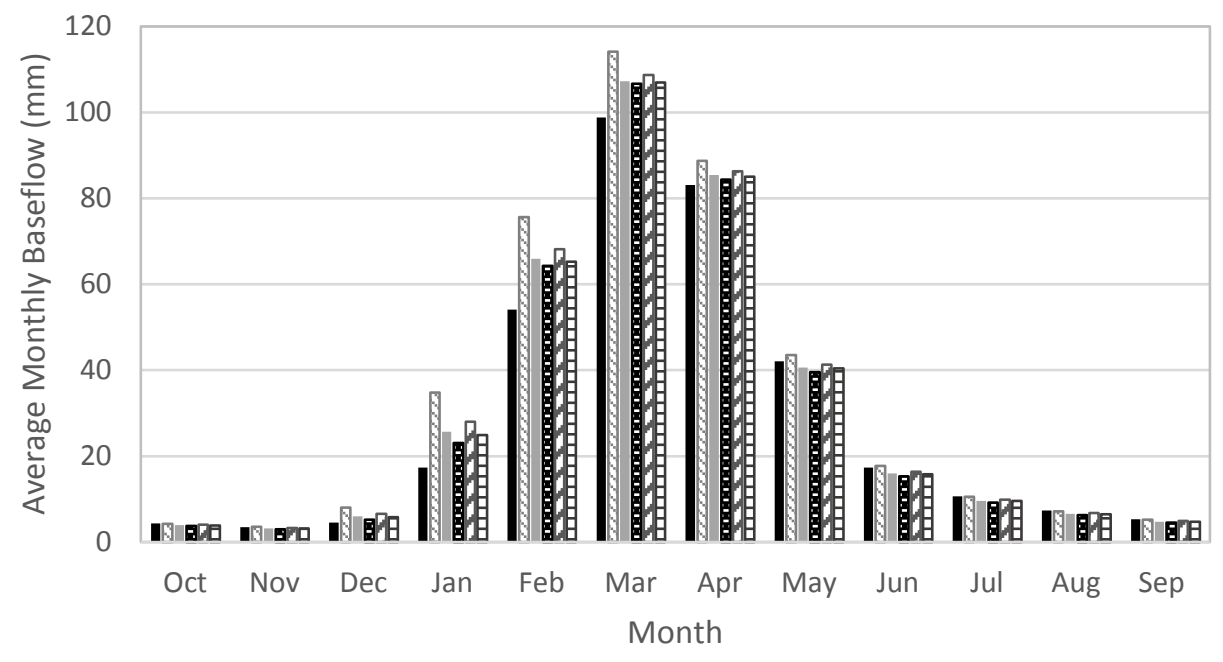

- Base $⿴ 囗$ Catchment 1 Catchment 2 田Catchment 3 口Catchment 4 日Catchment 5

Figure 5 Average monthly baseflow

\subsection{Transpiration}

The converse to the increased runoff is that there is a decrease in transpiration as there is less water stored in a thinner soil profile from which the vegetation can access. The monthly average transpiration model predictions are shown in Figure 6. This impact will be most noticeable during prolonged droughts rather than during the annual dry season. Anecdotal evidence of the rehabilitated sites suggest that this has not yet been detrimental to the rehabilitation success. The decrease in transpiration between a rehabilitated area and the pre-mine area is approximately $30 \%$ (pre-mine $=386 \mathrm{~mm}$ p.a. and rehabilitated $=267 \mathrm{~mm}$ p.a.).

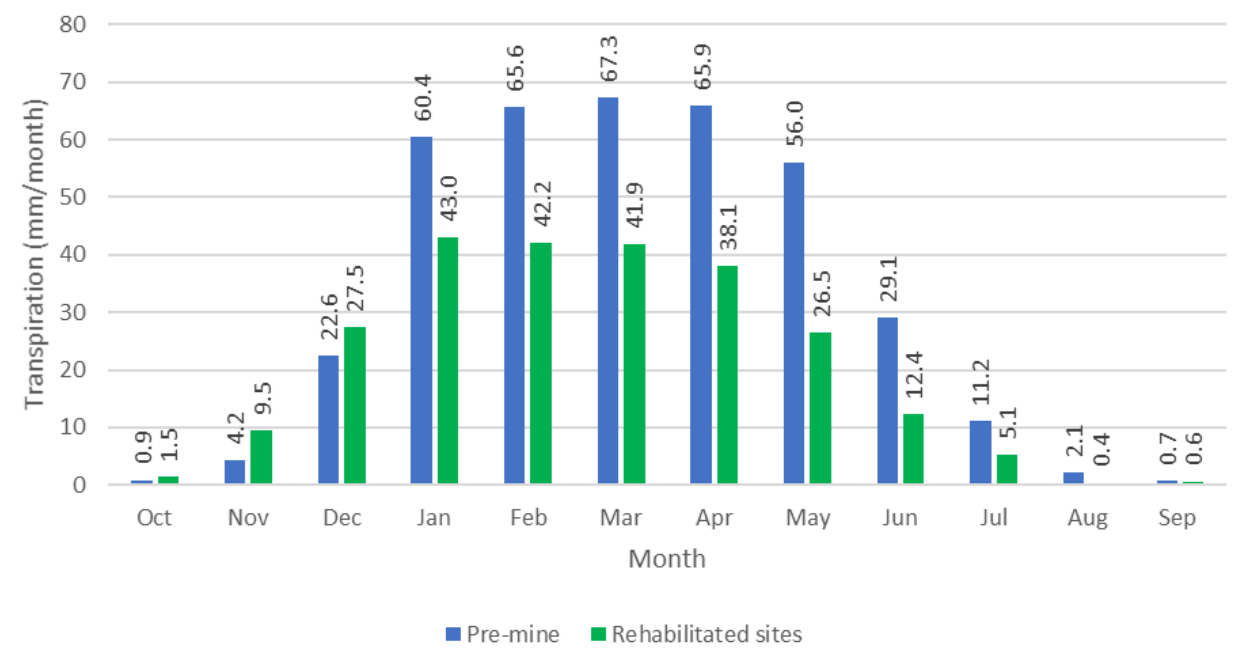

Figure 6 Average monthly transpiration for pre-mine and rehabilitated vegetation 


\subsection{Peak discharge}

The peak discharge was analysed for three scenarios:

1. Pre-mine - undisturbed catchment.

2. Post-mine A Scenario - catchment parameters adjusted to account for loss of bauxite (i.e. thinner soil profile) and runoff response for rehabilitated mining area due to the disturbed soil profile. The catchment boundaries are the same as the pre-mine scenario.

3. Post-mine B scenario - as per post-mine A scenarios, however with a reduction in extent (catchment area) due to the buffer areas around the waterways as these will affect the rapid response of runoff flowing into the waterways [As noted in the runoff section 3.1, it is assumed that that these buffers will not stop the eventual movement of runoff into the waterway, however the response time will be delayed with runoff seeping through the permeable buffer zones].

The highest peak discharge is achieved from the post-mine A scenario, with peak flows for $3 \%$ of the simulated time, which is during large rainfall events and higher runoff coefficient than scenario $B$. For the remaining $97 \%$ of the time, the thinner soils will produce higher peak discharges due to the soil profile being replenished and therefore reaching saturation faster. While the post-mine $A$ scenario demonstrates the impact of changes to the vegetation, it does not account for the impact of the buffers delaying the movement of runoff into the waterway. When this is accounted for there is a resulting reduction in peak discharge as shown by the results for the post-mine B scenario. In all catchments, this results in a decreased peak discharge, with Catchment 1 having the largest relative change as shown in the exceedance probability graphs in Figure 7. The peak discharge results for return periods from 2-years to 100-years are shown in Table 5.

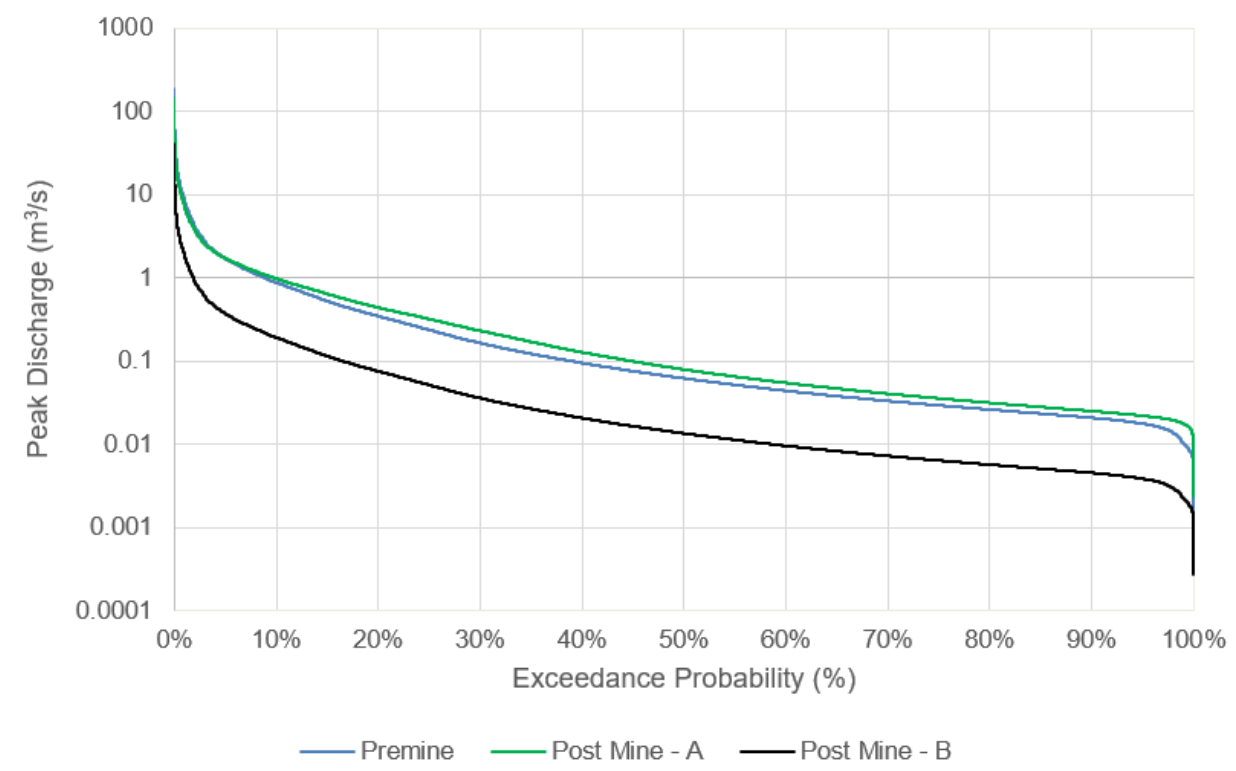

Figure $7 \quad$ Sample of the exceedance probability of peak discharge for Catchment 1 
Table $5 \quad$ Peak discharge for selected return periods

\begin{tabular}{|c|c|c|c|c|}
\hline \multicolumn{5}{|c|}{ Pre-mine } \\
\hline Return period & $\begin{array}{l}\text { Catchment } 1 \\
\text { Peak discharge } \\
\left(\mathrm{m}^{3} / \mathrm{s}\right)\end{array}$ & $\begin{array}{c}\text { Catchment } 2 \\
\text { Peak discharge } \\
\left(\mathrm{m}^{3} / \mathrm{s}\right)\end{array}$ & $\begin{array}{l}\text { Catchment } 3 \\
\text { Peak discharge } \\
\left(\mathrm{m}^{3} / \mathrm{s}\right)\end{array}$ & $\begin{array}{c}\text { Catchment } 4 \\
\text { Peak discharge } \\
\left(\mathrm{m}^{3} / \mathrm{s}\right)\end{array}$ \\
\hline 2 & 23.5 & 52.1 & 17.2 & 25.8 \\
\hline 5 & 43.4 & 92.6 & 31.1 & 47.6 \\
\hline 10 & 58.8 & 123.3 & 41.8 & 64.4 \\
\hline 20 & 74.5 & 154.8 & 52.7 & 81.7 \\
\hline 50 & 96.7 & 199.1 & 68.2 & 106.0 \\
\hline 100 & 114.8 & 235.3 & 80.8 & 125.8 \\
\hline \multicolumn{5}{|c|}{ Post-mine A-Scenario } \\
\hline 2 & 19.3 & 48.0 & 16.6 & 22.4 \\
\hline 5 & 34.9 & 84.3 & 29.8 & 41.1 \\
\hline 10 & 46.8 & 112.2 & 40.0 & 55.5 \\
\hline 20 & 58.9 & 141.2 & 50.4 & 70.4 \\
\hline 50 & 75.9 & 182.6 & 65.1 & 91.3 \\
\hline 100 & 89.8 & 216.9 & 77.2 & 108.5 \\
\hline \multicolumn{5}{|c|}{ Post-mine B-Scenario } \\
\hline 2 & 5.1 & 37.5 & 13.9 & 12.5 \\
\hline 5 & 9.5 & 66.5 & 25.2 & 23.1 \\
\hline 10 & 12.8 & 88.6 & 33.8 & 31.3 \\
\hline 20 & 16.2 & 111.3 & 42.6 & 39.6 \\
\hline 50 & 21.1 & 143.0 & 55.1 & 51.4 \\
\hline 100 & 25.0 & 169.0 & 65.3 & 61.1 \\
\hline
\end{tabular}

The peak discharge hydrographs from the ACRU agro-hydrological model were input into HEC-RAS 2D hydraulic model where four parameters were considered for analysis. These include, velocity, water surface elevation, bed shear stress, and stream power. The findings for each of the parameters are discussed in the subsequent sections for the four catchments that are the most effected by mining. The peak discharge values from the post-mine B scenario were used in the analysis of hydraulic impacts. The analysis was undertaken for the 2- and 50-year events. This is per the recommendations by the Australian Coal Association Research Program (ACARP) which is a guideline for the coal industry. As there is no guideline for bauxite mining, the ACARP guideline was adopted for this study. The reason for using the 2-year event is to identify the changes during a 'frequent' event, while the 50 -year event is a large event where changes will be noticed without it being an 'extreme' event.

\subsection{Velocity}

Catchment 1 is the most impacted catchment, and as a result has the largest change in velocity. For both the 2 -year and 50 -year events, the reduction in velocity is approximately $40 \%$. The peak velocity for the 2 -year event is approximately $1.5 \mathrm{~m} / \mathrm{s}$ and $2.2 \mathrm{~m} / \mathrm{s}$ for the 50 -year event. For the post-mine scenarios, the velocity 
for the 50-year event is effectively the same as the 2-year pre-mine event. The average velocity for the 2-year event is $0.63 \mathrm{~m} / \mathrm{s}$ and $0.36 \mathrm{~m} / \mathrm{s}$ and for the 50 -year event the average velocity is $0.96 \mathrm{~m} / \mathrm{s}$ and $0.61 \mathrm{~m} / \mathrm{s}$ for the pre- and post-mine scenarios respectively.

Catchment 2 is the largest of the four catchments considered for analysis. For both the 2-year and 50-year events, the average reduction in velocity is approximately $20 \%$ for the pre- and post-mine scenarios. The average velocity for the 2 -year event is $0.76 \mathrm{~m} / \mathrm{s}$ and $0.61 \mathrm{~m} / \mathrm{s}$ and for the 50 -year event the average velocity is $1.17 \mathrm{~m} / \mathrm{s}$ and $0.94 \mathrm{~m} / \mathrm{s}$ for the pre- and post-mine scenarios respectively. Catchment 3 shows a decrease in velocity of $10 \%$ and $7 \%$ for the 2 -year and 50 -year events respectively. The peak velocity for the pre-mine 2-year event is approximately $0.95 \mathrm{~m} / \mathrm{s}$ and $1.35 \mathrm{~m} / \mathrm{s}$ for the 50 -year event. The corresponding post-mine velocities are approximately $0.91 \mathrm{~m} / \mathrm{s}$ and $1.25 \mathrm{~m} / \mathrm{s}$ for the 2-year and 50 -year events respectively. The average velocity for the 2-year event is $0.39 \mathrm{~m} / \mathrm{s}$ and $0.36 \mathrm{~m} / \mathrm{s}$ and for the 50 -year event the average velocity is $0.61 \mathrm{~m} / \mathrm{s}$ and $0.57 \mathrm{~m} / \mathrm{s}$ for the pre- and post-mine scenarios respectively. Catchment 4 shows similar reductions in average flow velocity to Catchment 2 of $20 \%$ and $22 \%$ for the 2 -year and 50 -year events respectively. The average velocity for the 2 -year event is $0.76 \mathrm{~m} / \mathrm{s}$ and $0.61 \mathrm{~m} / \mathrm{s}$ and for the 50 -year event the average velocity is $1.17 \mathrm{~m} / \mathrm{s}$ and $0.94 \mathrm{~m} / \mathrm{s}$ for the pre- and post-mine scenarios respectively.

\subsection{Water surface elevation}

Catchment 1 has the largest change in water surface elevation (WSE) between pre- and post-mine conditions. On average, there is a $400 \mathrm{~mm}$ decrease in WSE between the pre- and post-mine scenarios for the 2-year event, while there is a $500 \mathrm{~mm}$ decrease in elevation for the 50 -year event. These reductions in WSE are large enough to have an impact on the extent to which the stream inundates the floodplain, which is important for maintaining a healthy riparian area. Catchment 2 has on average a $10 \mathrm{~mm}$ decrease in WSE between the pre- and post-mine scenarios for the 2-year event, while there is a $25 \mathrm{~mm}$ decrease in elevation for the 50-year event. Catchment 3 has on average a $70 \mathrm{~mm}$ decrease in WSE between the pre- and post-mine scenarios for the 2-year event, while there is a $120 \mathrm{~mm}$ decrease in elevation for the 50-year event. Catchment 4 has on average a $10 \mathrm{~mm}$ decrease in WSE between the pre- and post-mine scenarios for the 2 -year event, while there is a $20 \mathrm{~mm}$ decrease in elevation for the 50 -year event.

\subsection{Shear stress}

Catchment 1 shows a significant average reduction in shear stress of 51\% between the pre- and post-mine scenarios for the 2-year event and a reduction of $47 \%$ for the 50 -year event. For the 2-year event the shear stress is reduced from $9.1 \mathrm{~N} / \mathrm{m}^{2}$ to $4.4 \mathrm{~N} / \mathrm{m}^{2}$ on average. The average reduction in shear stress for the 50-year event is from $16.3 \mathrm{~N} / \mathrm{m}^{2}$ to $8.7 \mathrm{~N} / \mathrm{m}^{2}$. Catchment 2 shows a reasonably large average reduction in shear stress of $27 \%$ between the pre- and post-mine scenarios for both the 2-year and 50-year events. For the 2-year event the shear stress is reduced from $13.5 \mathrm{~N} / \mathrm{m}^{2}$ to $9.8 \mathrm{~N} / \mathrm{m}^{2}$ on average. The average reduction in shear stress for the 50 -year event is from $25.1 \mathrm{~N} / \mathrm{m}^{2}$ to $18.1 \mathrm{~N} / \mathrm{m}^{2}$. Catchment 3 shows an average reduction in shear stress of $11 \%$ between the pre- and post-mine scenarios for the 2-year event and a reduction of $9.7 \%$ for the 50 -year event. For the 2-year event the shear stress is reduced from $4.6 \mathrm{~N} / \mathrm{m}^{2}$ to $4.1 \mathrm{~N} / \mathrm{m}^{2}$ on average. The average reduction in shear stress for the 50 -year event is from $8.2 \mathrm{~N} / \mathrm{m}^{2}$ to $7.4 \mathrm{~N} / \mathrm{m}^{2}$. Catchment 4 also shows a reasonably large reduction in shear stress of $27 \%$ between the pre- and post-mine scenarios for the 2-year event and a reduction of $28 \%$ for the 50 -year event. For the 2 -year event the shear stress is reduced from $13.5 \mathrm{~N} / \mathrm{m}^{2}$ to $9.7 \mathrm{~N} / \mathrm{m}^{2}$ on average. The average reduction in shear stress for the 50 -year event is from $25.2 \mathrm{~N} / \mathrm{m}^{2}$ to $18.2 \mathrm{~N} / \mathrm{m}^{2}$.

\subsection{Stream power}

Catchment 1 has a significant reduction in average stream power of approximately $68 \%$ for the 2-year event and $64 \%$ for the 50 -year event. For the 2 -year event, the average reduction between pre- and post-mine scenarios is from $9.1 \mathrm{~W} / \mathrm{m}^{2}$ to $2.9 \mathrm{~W} / \mathrm{m}^{2}$. For the 50 -year event, the change between pre and post-mine scenarios is from $23.2 \mathrm{~W} / \mathrm{m}^{2}$ to $8.4 \mathrm{~W} / \mathrm{m}^{2}$. This means that the reduction in stream power of the 50 -year event is equivalent to approximately the 2 -year pre-mine event. Catchment 2 has a fairly large reduction in 
stream power of $41 \%$ and $42 \%$ for the 2-year and 50 -year events respectively. For the 2-year event, the average stream power changes from $16.0 \mathrm{~W} / \mathrm{m}^{2}$ to $9.4 \mathrm{~W} / \mathrm{m}^{2}$, while the 50 -year event changes from $44.4 \mathrm{~W} / \mathrm{m}^{2}$ to $25.8 \mathrm{~W} / \mathrm{m}^{2}$. Catchment 3 has a reduction in stream power of $12 \%$ and $11.3 \%$ for the 2-year and 50 -year events respectively. For the 2-year event, the average stream power changes from $3.3 \mathrm{~W} / \mathrm{m}^{2}$ to $2.9 \mathrm{~W} / \mathrm{m}^{2}$, while the 50 -year event changes from $8.7 \mathrm{~W} / \mathrm{m}^{2}$ to $7.4 \mathrm{~W} / \mathrm{m}^{2}$. Catchment 4 , similarly to Catchment 2, has a fairly large reduction in stream power of $40 \%$ and $42 \%$ for the 2-year and 50 -year events respectively. For the 2-year event, the average stream power changes from $15.9 \mathrm{~W} / \mathrm{m}^{2}$ to $9.4 \mathrm{~W} / \mathrm{m}^{2}$, while the 50 -year event changes from $44.5 \mathrm{~W} / \mathrm{m}^{2}$ to $25.7 \mathrm{~W} / \mathrm{m}^{2}$.

\section{Conclusion}

From this study, it can be concluded that the ACRU agro-hydrological model provides a useful tool for determining the hydrological impacts on a site for rehabilitation. The strength of the model lies in the fact that it is able to simulate complex soil-plant-atmosphere continuum processes and provide insight into the vegetation responses to changes in soil and topography as well as hydrological impacts. The ability to model these complex processes with limited field data is also beneficial for an OoM study. However, flow data against which to calibrate or compare modelled results is still preferable. The ACRU model is also able to provide input data for the HE-CRAS 2D model in order to estimate the relative hydraulic impacts to the waterways after being rehabilitated relative to a pre-mine scenario. From the results, an informed decision can be made as to how the mine wishes to proceed with the closure process in terms of the final landform such as whether or not to open the 'buffer areas' around the waterway to allow a more rapid response to rainfall events and thereby mimic pre-mine conditions more closely.

On an annual basis, the runoff in all impacted catchments is likely to increase between $3.5 \%$ and $13.5 \%$. The increase in annual runoff is as a result of the thinner soils being saturated quicker and having less storage capacity during the wet season. However, during the dry season, there is a reduction in runoff due to the thinner soil profile depleting quicker.

Peak discharge is reduced due to the change in the catchment topography as a result of the depressions caused by the removal of the bauxite. When modelled as a 'best case' scenario where only the soil thickness is decreased, there is a small increase in peak discharge. The aim for closure should be to route water back to the waterways where possible in order to achieve a peak discharge as close to pre-mine conditions as possible. While the buffers provide an effective control to minimise sediment release to the waterways from the active or non-rehabilitated mining areas, their use as a control for the final closure landform is not effective. The buffers result in a relative reduction in peak flows, flow velocities, shear stress and stream power in the waterways and will decrease the frequency of flow events that function to flush the natural sediment aggradation in the waterways. However, the impact on the waterways is not directly proportional to the change in hydraulic characteristics alone, as the buffers also reduce the sediment generation catchment of the waterways. Estimation of sediment yield was outside the scope of this study.

Similarly, to runoff, there is an annual increase in baseflow when compared to pre-mine conditions. The increase is largely due to increased baseflow in the wet season as the water is 'released' from the thinner soil profile quicker due to the smaller storage capacity. During the dry season, when baseflow would normally maintain some runoff, there is a reduction in baseflow. There is a reduction in transpiration of approximately $30 \%$ annually due to there being a smaller soil water store in the thinner soils. This should be taken into consideration when choosing species to revegetate during rehabilitation. However, anecdotal evidence suggests that there has been no impact on revegetation observed to date.

\section{References}

Banning, NC, Lalor, BM, Grigg, AH, Phillips, IR, Colquhoun, IJ, Jones, DL \& Murphy, DV 2011, 'Rehabilitated mine-site management, soil health and climate change', in BP Singh, AL Cowie \& KY Chan (eds), Soil Health and Climate Change, Springer, Berlin, pp. 287-315.

Croton, JT \& Ainsworth, GL 2007, 'Development of a winged tine to relieve mining related soil compaction', in NC Schenk (ed.), Methods and Principles of Mycorrhizal Research, The American Phytopathological Society, St Paul, pp. 29-36. 
Fox, ID, Nelder, VJ, Wilson, GW \& Bannink, PJ 2001, The vegetation of the Australian Tropical Savannas, Environmental Protection Agency, Queensland Government, Brisbane.

Isbell, RF 2002, The Australian Soil Classification, revised edition, CSIRO Publishing, Collingwood.

The International Union of Soil Sciences (IUSS) Working Group World Reference Base (WRB) 2007, World Reference Base for Soil Resources 2006, first update 2007, World Soil Resources Reports No. 103, Food and Agriculture Organization of the United Nations (FAO), Rome.

McKenzie, N, Jacquier, D, Isbell, RF \& Brown, K 2004, Australian Soils and Landscapes: An Illustrated Compendium, CSIRO Publishing, Collingwood.

O'Keefe, FD 1992, 'Bauxite mining and Walyamiri, the mining operation - paper one', Proceedings of the 17th Annual Environmental Workshop, Australian Mining Industry Council, Dickson, ACT, pp. 88-99.

Schäffer, B, Eggenschwiler, L, Suter, B, Vogt, L, Buchter, B, Pfister, H \& Schulin, R 2007, 'Influence of temporary stockpiling on the initial development of restored topsoils', Journal of Plant Nutrition and Soil Science, vol. 170, pp. 669-681.

Schmidt, EJ \& Schulze, RE 1987, 'Flood volume and peak discharge for small catchments in southern Africa, based on the SCS technique', Water Research Commission, Pretoria, Technical Report TT3/87, $142 \mathrm{p}$.

Schulze, RE 1995, ACRU Agrohydrological Modelling System, Department of Agricultural Engineering, University of Natal.

Soil Survey Staff 1999, Soil Taxonomy: A Basic System of Soil Classification for Making and Interpreting Soil Surveys, 2nd edn, US Department of Agriculture, Soil Conservation Service, Washington DC.

Spain, AV, Hinz, DA, Ludwig, JA, Tibbett, M \& Tongway, DJ 2015, 'The mining-restoration system and ecosystem development following bauxite mining in a biodiverse environment of the seasonally dry tropics of Australia', Mining in Ecologically Sensitive Landscapes, Commonwealth Scientific and Industrial Research Organisation, Australia.

Stace, HCT, Hubble, GD, Brewer, R, Northcote, KH, Sleeman, JR, Mulcahy, MJ \& Hallsworth, EG 1968, A Handbook of Australian Soils, Rellim Technical Publications, Glenside, South Australia.

US Army Corps of Engineers (USACE) 2018, Hydrological Engineering Centre - River Analysis System (HEC-RAS), Davis. 
